\title{
PENGARUH PROMOSI PENJUALAN DAN POTONGAN HARGA TERHADAP KEPUTUSAN PEMBELIAN KONSUMEN PRODUK KECANTIKAN WARDAH DI TOSERBA BOROBUDUR KEDIRI
}

\author{
Anggun Prabarini; Budi Heryanto; Puji Astuti \\ Fakultas Ekonomi - Universitas Kadiri \\ E-mail : budiheryanto@unik-kediri.ac.id
}

\begin{abstract}
This study aims to analyze the effect of sales promotions and price discounts on consumer purchasing decisions. The problems in this study are (1) How the influence of sales promotions on consumer purchasing decisions, (2) how the influence of price discounts on consumer purchasing decisions and (3) how the simultaneous influence between sales promotions and price discounts on consumer purchasing decisions. The population in this study were all wardah consumers at the Borobudur Kediri Department Store. Sampling using accidental sampling (roscoe) technique to obtain a sample of 60 respondents. Data collection methods used were questionnaires, interviews, documentation, and observation. The data analysis method used is the test instrument (validity test and reliability test), Multiple linear regression test analysis, $\mathrm{t}$ test and $\mathrm{F}$ test. The results of the study obtained multiple linear regression equation $\mathrm{Y}=17.117+$ $0.040 \mathrm{X} 1+0.254 \mathrm{X} 2+\mathrm{e}$. Based on the results of the study it can be concluded (1) There is no significant influence between sales promotions on purchasing decisions, (2) there is a significant effect between price cuts on consumer purchasing decisions and (3) there is a significant influence between sales promotions and price discounts on purchasing decisions consumer.
\end{abstract}

Keywords: sales promotion, price discounts, consumer purchasing decisions.

\begin{abstract}
Penelitian ini bertujuan untuk menganalisis pengaruh promosi penjualan dan potongan harga terhadap keputusan pembelian konsumen. Permasalahan dalam penelitian ini adalah (1) Bagaimana pengaruh promosi penjualan terhadap keputusan pembelian konsumen, (2) bagaimana pengaruh potongan harga terhadap keputusan pembelian konsumen dan (3) bagaimana pengaruh secara simultan antara promosi penjualan dan potongan harga terhadap keputusan pembelian konsumen. Populasi dalam penelitian ini adalah seluruh konsumen wardah di Toserba Borobudur Kediri. Penarikan sampel menggunakan teknik accidental sampling (roscoe) sehingga diperoleh sampel 60 responden. Metode pengumpulan data yang digunakan adalah kuesioner, wawancara, dokumentasi, dan observasi. metode analisis data yang digunakan adalah uji instrumen (uji validitas dan uji reliabilitas), Analisis uji Regresi linier berganda, Uji t dan uji F. Hasil penelitian diperoleh persamaan regresi linier berganda $\mathrm{Y}=17.117+0,040 \mathrm{X}_{1}+$ $0,254 \mathrm{X}_{2}+\mathrm{e}$. Berdasarkan hasil penelitian dapat disimpulkan (1) Tidak terrdapat pengaruh signifikan antara promosi penjualan terhadap keputusan pembelian, (2) terdapat pengaruh yang signifikan antara potongan harga terhadap keputusan pembelian
\end{abstract}


konsumen dan (3) terdapat pengaruh yang signifikan antara promosi penjualan dan potongan harga terhadap keputusan pembelian konsumen.

Kata Kunci : promosi penjualan, potongan harga, keputusan pembelian konsumen.

\section{PENDAHULUAN}

\section{Latar Belakang Masalah}

Era modern dan perkembangan zaman menyebabkan melonjaknya tingkat persaingan dalam dunia bisnis sebagai ikhtiar untuk menembus pasaran yang kian meluas. Kompetisi yang sengit dalam perdagangan ini tidak hanya dialami oleh satu perusahaan saja, karena hal ini juga dialami oleh hampir semua jenis peruahaan yang ada. Untuk mendapatkan tempat dipuncak persaingan maka dari itu setiap perusahaan dihimbau untuk lebih memperhatikan tingkat kepuasan konsumen yaitu dengan cara meningkatkan pelayanan. Dengan menjalankan cara tersebut dipercaya sanggup membantu meningkatkan profit dalam jangka panjang untuk perusahaan. Keuntungan yang diperoleh adalah dari pembelian produk oleh pelanggan.

Keahlian dalam menaikkan tingkat pembelian produk secara continue merupakan keutamaan bagi kelanjutan hidup suatu perusahaan. Yang termasuk dalam hal itu adalah pemasaran yang merupakan salah satu bagian krusial dalam usaha meningkatkan penjualan. Tempat, Promosi, harga, dan produk merupakan bagian dari marketing mix yang menjadi elemen penting dalam pembentukan program pemasaran pada suatu perusahaan. Merumuskan marketing mix dengan tepat diharuskan untuk dilakukan oleh perusahaan. Untuk meningkatkan penjualan, maka diperlukan strategi yang tepat untuk bersaing (Putra, 2014). Oleh karena itu feedback dari konsumen tidak dapat diabaikan begitu saja oleh perusahaan. Lantaran presensi pembeli sendiri menyandang peranan penting pada penerimaan akhir perusahaan yaitu meningkatnya profit dari hasil pembelian produk oleh pelanggan.

Dari hal tersebut diharapkan bahwa perusahaan dapat menangkap komponen apa saja yang dapat merangsang konsumen untuk mengambil keputusan pembelian sebuah produk. Promosi ialah salah satu faktor yang menentukan berhasil atau tidaknya suatu program pemasaran. Meskipun produk tersebut memiliki kualitas tinggi namun apabila konsumen belum mengenal dan belum mengetahui kegunaan produk tersebut bagi mereka maka konsumen tidak akan membeli produk tersebut. Tujuan promosi adalah untuk memberikan informasi dan persuasi kepada konsumen tentang produk yang dipasarkan. Melalui promosi inilah perusahaan menginformasikan tentang keunggulan 
dan kelebihan produk pada target pasar yang dijadikan sasaran, sehingga meningatkan penjualan produk tersebut.

Dengan bertambahnya jumlah perusahaan yang memproduksi jenis produk yang sama menciptakan persaingan antar perusahaan untuk merebutkan market share. Padahal jika dilihat lagi kebanyakan produk yang dipilih konsumen adalah produk yang sudah dikenal oleh kalangan luas dengan kualitas yang sudah teruji.

Hal ini mendorong perusahaan untuk menyusun strategi promosi yang efektif dan tepat sasaran agar konsumen tertarik untuk membeli produk yang ditawarkan. Salah satu strategi promosi yang sering digunakan adalah promosi penjualan dalam bentuk diskon harga. Diskon lebih sering digunakan dalam menarik pelanggan karena lebih menarik minat pelanggan dengan cepat dan efektif.

Dewasa ini persaingan pasar semakin kompetitif yang juga terjadi pada produk kosmetik. Untuk itu Wardah yang merupakan salah satu merek kosmetik di tanah air melakukan promo dan memberikan potongan harga untuk menarik minat beli konsumen. Salah satu contohnya adalah outlet Wardah yang berada di toserba Borobudur yang memberikan promo dan potongan harga sebesar $15 \%$ untuk semua pembelian produk wardah.

Dilihat dari latar belakang tersebut maka tujuan dari penelitian ini adalah untuk mengetahui pengaruh promosi penjualan dan potongan harga terhadap keputusan pembelian konsumen di toserba borobudur kediri (studi kasus produk kecantikan wardah)

\section{TINJAUAN PUSTAKA}

\section{Penelitian terdahulu}

Menurut penelitian dari Rizky Y.S Emor dan Agus Supandi Soegoto, Jurnal EMBA Vol.3 No.2 Juni 2015, Hal. 738-748 (2015) dengan judul "Pengaruh Potongan Harga, Citra Merek, Dan Servicescape Terhadap Keputusan Pembelian Konsumen Indomaret Tanjung Batu" memperoleh hasil variabel Potongan Harga memiliki pengaruh positif terhadap Keputusan Pembelian Konsumen Indomaret Tanjung Batu. Citra Merek memiliki pengaruh positif terhadap Keputusan Pembelian Konsumen Indomaret Tanjung Batu. Servicescape memiliki pengaruh positif berpengaruh terhadap Keputusan Pembelian Konsumen Indomaret Tanjung Batu. Citra Merek memiliki pengaruh yang dominan terhadap Keputusan Pembelian.

Menurut penelitian dari Faridha Anggraeni, Jurnal Ilmu dan Riset Manajemen : Volume 5, Nomor 7, Juli 2016 dengan judul "Pengaruh Promosi, Diskon dan Impulse 
Buying Terhadap Keputusan Pembelian Hypermarket Ptc Surabaya" hasil uji yang telah dilakukan pada penelitian ini menghasilkan pengaruh positif signifikan.

Menurut penelitian dari Doni Hariadi, Jurnal Ilmu dan Riset Manajemen Vol. 1 No. 8 (2012) dengan judul "Pengaruh Produk, Harga, Promosi dan Distribusi terhadap keputusan Pembelian Konsumen pada Produk Projektor Mikrovision" hasil dari penelitian ini menyatakan adanya pengaruh yang positif dan signifikan.

Menurut penelitian dari Didar Adinda (2013) Pengaruh Promosi dan Potongan Harga Terhadap Keputusan Pembelian Pada Butik Fourgirls Medan memperoleh hasil promosi dan potongan harga memiliki pengaruh positif dan signifikan terhadap keputusan pembelian pada butik Fourgirls, Medan, berdasarkan uji sigmultan. Promosi dan potongan harga juga memiliki kaitan yang cukup erat dengan keputusan pembelian pada Butik Fourgirls, Medan berdasarkan koefisien determinan (R2). Uji parsial menunjukkan bahwa porongan harga memiliki pengaruh positif dan signifikan sedangkan promosi tidak memiliki pengaruh yang signifikan keputusan pembelian terhadap Butik Fourgirls, Medan

\section{Promosi Penjualan (X1)}

\section{Pengertian Promosi}

Pengertian “ Promosi Menurut Kotler ( 2012 : 93) Promosi merupakan keaktifan yang mengonsumsi kegunaan produk dan menyakinkan konsumen untuk membelinya . Dari pengertian diatas dapat dijelaskan kembali bahwa calon pembeli akan membeli produk yang diinginkan ketika mereka mengetahui kekurangan dan kelebihan produk dibanding produk pesaing “.

Kegiatan promosi biasanya dilakukan secara langsung atau mauapun tidak langsung. Kegiatan ini dapat dilakukan dengan berdasarkan pada tujuan promosi sehingga dapat membantu perusahaan dalam mencapai tujuan yang dikehendakinya. Secara garis besar tujuan yang dikehendaki dapat dibagi 2, antara lain : Tujuan jangka pendek dan Tujuan jangka panjang.

Menurut "Swastha dan Irawan ( 2010:321), tujuan promosi antara lain : Memodifikasi Tingkah Laku konsumen, Memberitahukan konsumen, Membujuk konsumen untuk melakukan pembelian dan Mengingatkan konsumen terhadap produk yang ditawarkan".

\section{Potongan Harga (X2)}

\section{Pengertian Potongan Harga}

Potongan harga adalah salah satu strategi bisnis yang dianggap sangat efektif pada saat ini. Tujuan dari diadakannya potongan harga adalah untuk menjaga stabilitas 
perputaran uang. Perputaran uang ini digunakan untuk membiayai operasioanl, tenaga kerja dan biaya lain yang terkait dengan daur hidup perusahaan. Dalam sebuah transaksi dagang selalu ada dua orang atau lebih yang terlibat didalamnya sebagai penjual dan pembeli. Sebelum adanyab transaksi maka harus ada kesepakatan tentang barang, harga dan potongan harga atau diskon yang diberikan untuk konsumen. Pemberian potongan harga atau diskon diharapkan bisa menjadi pendorong yang mempengaruhi keputusan pembelian.

Simamora (2010:154) “ mengemukakan bahwa potonngan harga adalah potongan tunai yang ditawarkan untuk diberikan kepada para konsumen yang akan membeli produk yang kita tawarkan.” Menurut " Ismaya (2005:252) potonngan harga adalah potongan terhadap harga penjualan yang telah disetujui apabila pembayaran dilakukan dalam jangka waktu yang lebih cepat dari jangka waktu kredit, potonngan harga adalah potongan tunai dipandang dari sudut penjual.”

\section{Jenis-Jenis Potonngan Harga}

Ada berbagai potongan harga yang diberikan oleh perusahaan kepada konsumen. Potongan harga atau diskon diharapkan bisa mendorong konsumen untuk membeli produk yang kita tawarkan. Menurut “ Kotler (2012 :537) ada 5 macam diskon atau potongan harga, antara lain: Potongan harga tunai, Potongan Kuantitas diberikan saat konsumen membeli dalam jumlah yang banyak atau grosir, Potongan Harga Fungsional, ini hanya diperuntukkan anggota yang mempunyai fungsi tertentu, Potongan Harga Musiman hanya pada saat tertentu diberikan, Potongan Harga biasa” .

\section{Keputusan Pembelian (Y)}

"Keputusan pembelian menurut Schiffman dan Kanuk (2004 : 547) adalah pemilihan dari dua atau lebih alternatif pilihan keputusan pembelian, artinya bahwa seseorang dapat membuat keputusan, haruslah tersedia beberapa alternatif pilihan. Keputusan untuk membeli dapat mengarah kepada bagaimana proses dalam pengambilan keputusan tersebut itu dilakukan”.

Bentuk proses pengambilan keputusan tersebut dapat digolongkan sebagai berikut: 1. Fully Planned Purchase, 2. Partially Planned Purchase, 3. Unplanned Purchas.

Menurut Kotler (2012:204), pada umumnya konsumen melewati lima tahap dalam proses keputusan pembelian yaitu (1) pengenalan kebutuhan, (2) pencarian informasi, (3) evaluasi alternatif, (4) keputusan pembelian, (5) perilaku pasca 
pembelian. Berdasarkan atas tinjauan teoritis diatas maka dapat digambarkan kerangka konseptual sebagai berikut :

Gambar. Kerangka Konseptual Penelitian

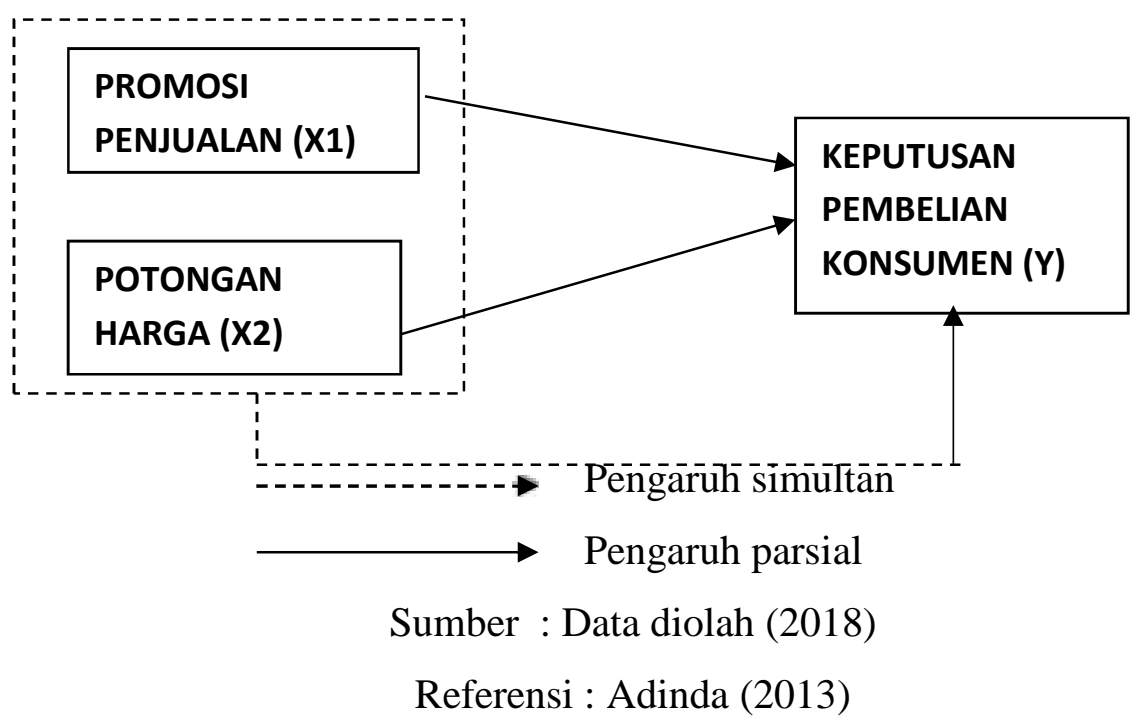

\section{Hipotesis}

Hipotesis dalam penelitian ini sebagai berikut :

H1 : Promosi penjualan berpengaruh positif terhadap keputusan pembelian konsumen pada produk wardah di toserba borobudur Kediri.

H2 : Potongan harga berpengaruh positif terhadap keputusan pembelian konsumen pada produk wardah di toserba borobudur Kediri..

H3 : Promosi penjualan dan Potongan harga berpengaruh secara simultan terhadap keputusan pembelian konsumen pada produk wardah di toserba borobudur Kediri.

\section{METODE PENELITIAN}

\section{Populasi dan Sampel Penelitian}

Konsumen produk merek wardah pada Toserba Borobudur di Kediri yang tidak diketahui jumlah pastinya merupakan populasi dari penelitian ini. Penentuan ukuran sampel dari populasi menggunakan teori dari Roscoe dalam Sugiyono (2016:103), yang menyatakan bahwa jumlah anggota sampel minimal 10 kali dari jumlah variabel (independent + dependent) yang diteliti. Maka jumlah anggota sampel yang diambil 20. Dalam penelitian ini terdapat 3 variabel yang berarti $20 \times 3=60$ orang sampel. Teknik pengambilan sampelnya menggunakan metode accidental sampling. 


\section{Metode Analisis Data}

\section{Uji Instrumen Penelitian :}

\section{Uji Validitas}

Uji Validitas menurut Ghozali (2011:45) “digunakan untuk mengukur sah atau valid tidaknya suatu kuesioner. Dalam hal ini koefisien korelasi yang nilai signifikannya lebih kecil dari 5\% (level of significance) menyatakan bahwa pernyataan-pernyataan tersebut sudah sahih sebagai pembentuk indikator".

\section{Uji Reliabilitas}

Ghozali (2011:47) "mengatakan reliabilitas adalah suatu angka yang menunjukkan konsistensi suatu alat ukur didalam mengukur objek yang sama”. Suatu konstruk variabel dikatakan baik jika memiliki nilai alpha cronbach's > 0,60.

\section{Analisis Regesi Linier Berganda}

Analisis regresi linier berganda digunakan untuk menguji hipotesis tentang antara hubungan dua vaiabel bebas atau lebih secara bersama-sama dengan suatu variabel tergantung. Yang dihitung dengan menggunakan rumus :

$\boldsymbol{Y}=\boldsymbol{a}+\boldsymbol{b}+\boldsymbol{b}+\boldsymbol{e}$

\section{Uji Hipotesis}

Uji hipotesis dalam penelitian ini menggunakan uji t dan uji $\mathrm{F}$

\section{Uji Simultan (Uji F)}

Menurut sugiyono (2007:235) "Uji F digunakan untuk mengetahui apakah variabel bebas $(\mathrm{X})$ secara simultan berpengaruh signifikan terhadap variabel terikat $(\mathrm{Y})$ ".

\section{Uji Parsial (Uji t)}

Uji T digunakan untuk membuktikan signifikansi antar variabel yang diteliti dalam sebuah penelitian.

\section{HASIL DAN PEMBAHASAN}

\section{Hasil Penelitian}

\section{Uji Validitas}

Hasil dari uji validitas pada instrumen penelitian ini dengan nilai $r$ tabel 0,263. Untuk uji validitas X1 yang terdiri dari x1.1 memperoleh nilai 0,481, x1.2 memperoleh nilai 0,738 , x1.3 memperoleh nilai 0,645 , x1.4 memperoleh nilai 0,607 . Untuk item 
instrumen variabel X2 menunjukkan nilai sebagai berikut : x2.1 memperoleh nilai 0,796, x2.2 memperloeh nilai 0,805 dan x2.3 memperoleh nilai 0,822. Dan untuk yang terakhir adalah item dari variabel $\mathrm{Y}$ menunjukkan nilai sebagai berikut : Y.1 memperoleh nilai 0,310, Y.2 memperoleh nilai 0,628, Y.3 memperoleh nilai 0,711, Y.4 memperoleh nilai 0,545 dan Y.5 memperoleh nilai 0,601.

Berdasarkan hasil uji Validitas yang dilakukan terhadap item instrumen yang digunakan dalam penelitian menunjukkan bahwa semua item instrumen penelitian dapat dikatakan valid karena telah memenuhi kriteria pengujian validitas.

\section{Uji Reliabilitas}

Berdasarkan hasil perhitungan model Cronbach'sAlpha menunjukkan bahwa Promosi penjualan reliabel dengan hasil perhitungan 0,737 dimana hasil tersebut lebih besar dari 0,6. Selanjutnya Potongan Harga juga reliabel dengan nilai perhitungan 0,830 dimana hasil tersebut lebih besar dari 0,6. Keputusan Pembelian Kosumen juga reliabel dengan nilai perhitungan 0,713 dimana hasil tersebut lebih besar dari 0,6. Jadi, dengan demikian semua item instrumen penelitian dapat dikatakan reliabel karena telah memenuhi kriteria pengujian reliabilitas.

\section{Analisis Regresi Linier Berganda}

Berikut adalah hasil uji regresi berganda pada penelitian ini yang dapat dilihat di tabel 2.

`Tabel 1. Hasil Uji Regresi Linier Berganda

Coefficients $^{\mathbf{a}}$

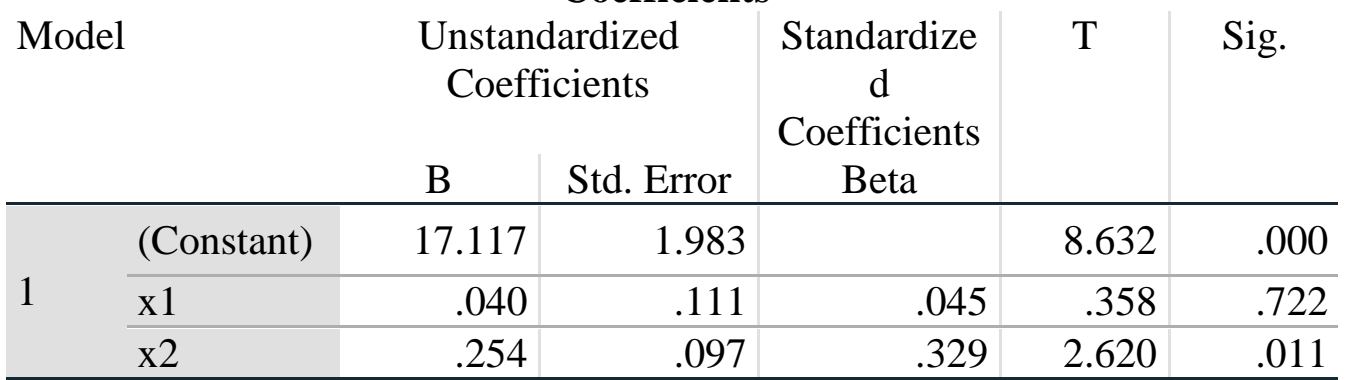

a. Dependent Variable: y

Sumber : Data primer yang diolah menggunakan spss (2018)

$$
\mathrm{Y}=17.117+0,040 \mathrm{X}_{1}+0,254 \mathrm{X}_{2}+\mathrm{e}
$$

\section{Uji Hipotesis}

\section{uji Parsial (Uji t)}

Berdasarkan uji parsial / uji T dapat disimpulkan bahwa hasil uji regresi parsial sebagai berikut : 


\section{Promosi Penjualan(x1)}

Hasil statistik uji t untuk variabel kepuasan konsumen diketahui bahwa nilai $t_{\text {hitung }}$ sebesar 0,358 dengan nilai signifikansi sebesar 0,722 dimana lebih besar dari 0,05 $(0,722>0,05)$, dan koefisien regresi mempunyai nilai positif sebesar 0,040. Maka secara parsial tidak berpengaruh signifikan, tetapi bila diuji secara simultan variabel ini mempunyai pengaruh yang signifikan antara variabel Promosi Penjualan terhadap variabel Keputusan Pembelian konsumen.

2. Potongan Harga (x2)

Hasil statistik uji t untuk variabel Potongan Harga diketahu bahwa nilai thitung sebesar 2,620 dengan nilai signifikansi sebesar 0,011 dimana lebih kecil dari 0,05 $(0,00<0,05)$ dan koefisien regresi mempunyai nilai positif sebesar 0,254. Maka secara parsial ada pengaruh yang signifikan antara variabel Potongan Harga terhadap variabel Keputusan Pembelian konsumen.

\section{Uji F / Uji Simultan}

Setelah dilakukan uji F/ uji simultan diperoleh hasil bahwa nilai Fhitung sebesar 3,656 lebih besar dari nilai Ftabel 1,53 (3,656>1,53) dengan batas signifikansi 0,05. nilai signifikan sebesar 0,032<0,05 yang artinya H0 ditolak dan Ha diterima. Dari perhitungan tersebut membuktikan bahwa secara bersama-sama (simultan) Promosi Penjualan(X1) dan Potongan Harga $\left(\mathrm{X}_{2}\right)$ berpengaruh signifikan terhadap Keputusan Pembelian konsumen (Y).

\section{Pembahasan Penelitian}

Berdasarkan hasil analisis regresi berganda diketahui bahwa secara parsial membuktikan bahwa variabel Promosi Penjualan $\left(\mathrm{X}_{1}\right)$ tidak berpengaruh signifikan terhadap variabel Keputusan Pembelian konsumen sedangkan variabel Potongan Harga $\left(\mathrm{X}_{2}\right)$ berpengaruh secara signifikan terhadap variabel Keputusan Pembelian konsumen (Y).

Secara simultan Promosi Penjualandan Potongan Harga berpengaruh signifikan Keputusan Pembelian konsumen.

Penjelasan masing-masing variabel sebagai berikut :

1. Tidak ada pengaruh signifikan antara Promosi Penjualan terhadap Keputusan Pembelian konsumen. Hasil uji hipotesis menunjukkan tidak ada pengaruh signifikan antara variabel Promosi Penjualan terhadap Keputusan Pembelian 
konsumen. Penilaian sebagian responden menyatakan Promosi Penjualan belum mampu memenuhi kebutuhan dan keinginan yang sesuai dengan harapan konsumen. Hal ini bertolak belakang dengan hasil penelitian yang dilakukan oleh Didar Adinda

2. Ada pengaruh yang signifikan antara variabel Potongan Harga terhadap Keputusan Pembelian konsumen. Hasil uji hipotesis menunjukkan ada pengaruh antara Potongan Harga terhadap Keputusan Pembelian konsumen. Hal ini sesuai dengan penelitian yang dilakukan oleh Rizky Y.S Emor,dkk (2015) dan (Pangastuti, 2018). Dengan demikian maka penelitian di atas sesuai dengan uji hipotesis yaitu terdapat pengaruh secara signifikan antara Potongan Harga terhadap Keputusan Pembelian konsumen.

3. Terdapat pengaruh yang signifikan secara simultan (bersama-sama) antara Promosi Penjualan dan Potongan Harga Terhadap Keputusan Pembelian Konsumen. Hasil yang diperoleh menunjukkan adanya pengaruh secara simultan antara Promosi Penjualan dan Potongan Harga Terhadap Keputusan Pembelian Konsumen. Hal ini didukung oleh penelitian yang dilakukan oleh Didar Adinda (2013).

\section{KESIMPULAN DAN SARAN}

\section{Kesimpulan}

Dari hasil penilitian yang dilakukan berkaitan dengan pengaruh Promosi Penjualan dan Potongan Harga Terhadap Keputusan Pembelian Konsumen, maka dapat disimpulkan sebagai berikut:

1. Hasil pengujian secara parsial menunjukkan tidak ada pengaruh signifikan antara variabel Promosi Penjualan terhadap variabel Keputusan Pembelian Konsumen yang dibuktikan dengan nilai signifikansi sebesar 0,722 dimana lebih besar dari 0,05 $(0,722>0,05)$.

2. Hasil pengujian secara parsial menunjukkan bahwa ada pengaruh secara signifikan antara variabel Potongan harga terhadap variabel Keputusan Pembelian konsumen dengan nilai signifikansi 0,011 dimana lebih kecil dari $0,05(0,011<0,05)$.

3. Hasil pengujian simultan menunjukkan pengaruh variabel Promosi Penjualan dan Potongan harga secara bersama-sama berpengaruh signifikan terhadap Keputusan Pembelian konsumen. Hasil ini mengindikasikan bahwa tingkat Keputusan Pembelian 
konsumen wardah di Toserba Borobudur Kediri ditentukan oleh seberapa baik tingkat Promosi Penjualan dan seberapa tinggi tingkat Potongan harga pada merek tersebut. Hubungan antara variabel Promosi Penjualan dan Potongan harga secara bersama-sama terhadap Keputusan Pembelian konsumen memiliki hubungan yang cukup erat. Kondisi ini diindikasikan dengan perolehan tingkat signifikan kedua variabel tersebut kurang dari $5 \%(0,05)$.

\section{Saran}

Manajemen selalu meningkatkan promosi penjualan dengan memastikan produk memiliki kualitas yang baik, ciptakanlah tekhnik pemasaran yang baik dengan didukung oleh strategi pemasaran yang efektif dengan mengenali pelanggan anda, menentukan lokasi strategis, menggunakan internet marketing dengan menampilan produk pada situs jejaring sosial, turut berpartisipasi dalam event-event, dan menjaga hubungan baik dengan pelanggan.

\section{DAFTAR PUSTAKA}

Arikunto, Suharsimi, 2008. Prosedur Penelitian, Edisi Revisi V, Rineka Cipta, Jakarta. , 2002. Prosedur Penelitian: Suatu Pendekatan Praktek, Rineka Cipta, Jakarta.

Didar Adinda, 2013. Pengaruh Promosi dan Potongan Harga Terhadap Keputusan Pembelian Konsumen Pada Butik Fourgirls Medan, Universitas Sumatera Utara. Skripsi.

Djaalii. 2008. Psikologi Pendidikan. Bumi Aksara. Jakarta.

Doni Hariadi, 2012, Pengaruh Produk, Harga, Promosi dan Distribusi terhadap keputusan Pembelian Konsumen pada Produk Projektor Mikrovision, Vol. 1 No. 8.

Engel, James. F, Roger D. Blackwell dan Paul W. Miniard. 2011. Prilaku Konsumen. Jakarta. Binarupa Aksara.

Faridha Anggraeni, 2016, Pengaruh Promosi, Diskon dan Impulse Buying Terhadap Keputusan Pembelian Hypermarket Ptc Surabaya, Volume 5, Nomor 7.

Ghozali, I. 2011. Aplikasi Analisis Multivariate dengan Program SPSS.(Trans: Application) of Multivariate Analysis using SPSS). Badan Penerbit UNDIP,ISBN 979.704.300.2. Semarang.

Indriyanto \& Supomo, Bambang. 2009. Metodologi Penelitian Bisnis untuk Akuntansi dan Manajemen. Edisi Pertama. BPFE Yogyakarta. Yogyakarta.

Ismaya, Sujana, 2006, Kamus Manajemen, Cetakan Pertama, Bandung : Pustaka Grafika.

Kotler, Philip and Gary Armstrong. 2012. Principles of Marketing, Edisi Keempatbelas, Pearson Education, New Jersey. 
dan Keller. 2009. Manajeman Pemasaran. Edisi Ketigabelas Jilid 2.Erlangga. Jakarta. . 2007. Manajemen pemasaran .Edisi 12. Benyamin Molan (penerjemah). Marketing Management. PT. Indeks. Jakarta.

Mamang Sangadji, Etta dan Sopiah, 2010. Metodologi Penelitian, Penerbit Andi, Yogyakarta

Pangastuti, R. L. (2018). The Influence of Experiential Marketing And Service Quality For being Reasonability of Customers Loyality Forming (Case Study of Beauty Saloon of London Beauty Center " LBC"). Ekonika: Jurnal Ekonomi Universitas Kadiri, 2(2), 198. https://doi.org/10.30737/ekonika.v2i2.43

Putra, Y. P. (2014). Formulasi Strategi Bersaing Pada Universitas Kadiri Dalam Menghadapi Persaingan Antar Perguruan Tinggi Sejenis di Kota Kediri. Universitas Airlangga, Surabaya.

Rizky Y.S Emor dan Agus Supandi Soegoto, 2015, Pengaruh Potongan Harga, Citra Merek, Dan Servicescape Terhadap Keputusan Pembelian Konsumen Indomaret Tanjung Batu, Vol.3 No.2 Juni 2015, Hal. 738-748.

Sangadji, EM, dan Sopiah. 2013. Perilaku Konsumen: Pendeatan Praktis. Disertai: Himpunan Jurnal Penelitian, Andi. Yogyakarta.

Schiffman dan Kanuk. 2004. Perilaku Konsumen. Edisi Ketujuh. Jakarta: PT Indeks. 2010. Perilaku Konsumen. Edisi Kesepuluh. Jakarta: PT Indeks.

Shinta, Agustina. 2011. Manajemen Pemasaran. Universitas Brawijaya Press, Malang.

Simamora, Henry. 2010. Manajemen Pemasaran Internasional. Jilid II, Cetakan Pertama. Jakarta: Salemba Empat.

Sugiyono,. 2011. Metode Penelitian Pendidikan (Pendekatan Kuantitatif, Kualitatif,dan $R \& D)$. Alfabeta. Bandung. , 2008. Metode Penelitian Bisnis, Alfabeta, Bandung. 2009. Metode Penelitian Kuantitatif, Kualitatif dan $R \& D$. Alfabeta. Bandung. ,. 2011. Metode Penelitian Pendidikan (Pendekatan Kuantitatif, Kualitatif,dan $R \& D)$. Alfabeta. Bandung. . 2012. Metode Penelitian Pendidikan. Alfabeta. Bandung. .2014. Metode Penelitian Pendidikan Pendeatan Kuantitatif. Alfabeta. Bandung. . 2016. Metode Penelitian Kuantitatif, Kualitatif dan R\&D. Alfabeta. Bandung.

Swastha, Basu 2009. Manajemen Penjualan, Edisi Ketiga, BPFE, Yogyakarta. , dan Hani Handoko. 2010. Manajemen Pemasaran: Analisa Perilaku Konsumen. Liberty: Yogyakarta

Tjiptono, Fandy. 2006. Manajemen Pelayanan Jasa. Penerbit Andi. Yogyakarta. , 2008. Strategi Pemasan, Edisi 3. Penerbit Andi. Yogyakarta.

Zaltman, Gerald, dan Wallendorf, Melanie.1976. Consumer Behavior, Second Edition, Englewood Cliffs, New Jersey. 